\title{
Impact of 2nd Wave of COVID-19 Related Lockdown on Coastal Water Quality at Diu, Western Coast of India and Role of Total Alkalinity on Bacterial Loads
}

\section{Atanu Kumar Panja}

Central Salt and Marine Chemicals Research Institute CSIR

\section{Sonpal Vasavdutta}

Central Salt and Marine Chemicals Research Institute CSIR

\section{Tarini Prasad Sahoo}

Central Salt and Marine Chemicals Research Institute CSIR

\section{Ambika Hemant Shinde}

Central Salt and Marine Chemicals Research Institute CSIR

Ravikumar Bhagawan Thorat

Central Salt and Marine Chemicals Research Institute CSIR

Shruti Chatterjee

Central Salt and Marine Chemicals Research Institute CSIR

\section{Sanak Ray}

Central Salt and Marine Chemicals Research Institute CSIR

\section{Anil Kumar Madhava}

Central Salt and Marine Chemicals Research Institute CSIR

Soumya Haldar ( $\nabla$ shaldar@csmcri.res.in )

Central Salt and Marine Chemicals Research Institute https://orcid.org/0000-0001-9989-8137

\section{Research Article}

Keywords: Alkalinity, Bacterial loads, COVID-19, Diu, Fluctuation, Lockdown, Mann-Kendall trend

Posted Date: December 6th, 2021

DOI: https://doi.org/10.21203/rs.3.rs-1067191/v1

License: (c) (1) This work is licensed under a Creative Commons Attribution 4.0 International License. Read Full License 
19168-0.

Page $2 / 18$ 


\section{Abstract}

A detailed coastal water monitoring near Diu coast, western part of India was performed from October, 2020 to May, 2021 covering the $2^{\text {nd }}$ lockdown time. Average monthly fluctuation from 7 different sampling stations of total 9 physico-chemical parameters such as $\mathrm{pH}$, salinity, turbidity, nitrite $\left(\mathrm{NO}_{2}\right)$, nitrate $\left(\mathrm{NO}_{3}\right)$, ammonia $\left(\mathrm{NH}_{3}\right)$, phosphate $\left(\mathrm{PO}_{4}\right)$, total alkalinity and silicate were recorded. Initially, MannKendall trend test for all the 9 parameters showed non-zero trend, which may be either linear or non-linear. During $2^{\text {nd }}$ lockdown period, there was a fluctuation of value for parameters like $\mathrm{pH}$, salinity, nitrate, nitrite and phosphate. Average total bacterial count and differential bacterial count also gradually decreased from March, 2021 sampling. Principal component analysis (PCA) plot covering all the physico-chemical parameters as well as the differential bacterial count showed a distinct cluster of all bacterial count with total alkalinity value. Subsequently, mathematical equation was formulated between total alkalinity value and all differential bacterial count. Upto our knowledge this is the first report where mathematical equation was formulated to obtain value of different bacterial load based on the derived total alkalinity value of the coastal water samples near Diu, India.

\section{Introduction}

Diu is one of the popular tourist destination and also it is considered as one of the major fish landing centre and fishing harbour. Ministry of Tourism, Government of India data showed that in the year 2014, a total of 2.2 million domestic and 0.1 million tourists visited Diu (NIP, 2020) and the number has increased further. However, similar to other part of country, due to COVID-19 lockdown there was total restriction in tourists entry at Diu from April 2020 onwards, which was eased at low pace from September, 2020 (1st wave). Further there was another restriction during March-May, 2021 due to 2 nd wave of COVID-19 in the country. Another important source of livelihood at Diu is marine fishery and in fishery sector, there are more than 100 big mechanized trawlers, around 50 numbers of mechanized fibre-reinforced plastic (FRP) and 250 motorized FRP operated from this fishing harbour regularly (Diu Fisheries Department, 2013). Diu coast length is around $27 \mathrm{~km}$ of which number of landing centre are 12. A total of 3,100 fishermen families are involved in fishing activity, majority of which is coastal or deep sea fishing (Department of Fisheries, 2019).

Due to COVID-19 related lockdown from April 2020, there was a complete halt in all the anthropogenic activities throughout the country and all the other activities were also closed. Total marine catch in Diu increased from 27,000 tons in 2018-19 to 31,800 tons in 2019-20 (Fishery office, Diu). However, there is a drastic reduction in the year 2020-21 due to pandemic related reduction in fishing activities (personal communication, data not available so far). Recently our group has reported the self-replenshing capacity of Alang ship recycling yard (the world largest ship recycling yard), area located $30 \mathrm{~km}$ away from Diu, and it was clearly shown that due to cessation of anthropogenic activities, during April-May, 2020; there is a considerable reduction in different physico-chemical parameters in both coastal water and sediment samples as well as in the ambient air (Chanchpara et al., 2021). In another recent study, it has already 
been reported that different anthropogenic activities are the source of water pollution (Lotliker et al., 2021). Further, the coastal water of India in the vicinity of major cities are strongly influenced by the anthropogenic discharges (Zingde and Govindan, 2000; Verlecar et al., 2006; Khatri and Tyagi, 2015; Gopal et al., 2018). However, there is no such study in comparatively pristine environment like Diu where anthropogenic impacts are mostly depend on the tourist inflow and fishing related activities. CSIR-

CSMCRI has initiated a project to monitor the monthly physico-chemical and biological parameters of Diu coast from October, 2020.

Based on all the data, the objective of the present work is (1) to understand the impact of 2nd lockdown (March-May, 2021) with respect to different physico-chemical as well as biological parameters including bacterial distribution in comparison to the previous months when normal activities prevailed (2) attempt will be made to identify the physico-chemical factor which can regulate bacterial load and (3) further attempt will be made to develop an algorithm to co-relate between different bacterial counts and the identified physico-chemical parameter. Upto our understanding this is the first report where attempt is made to correlate specific physico-chemical parameter and bacterial load based on mathematical equation. This work will definitely help to understand the coastal health of other area when selected physico-chemical parameters are available. This study will also help to improve the coastal management by restricting the release of selected parameters which indirectly reduce the load of the pathogenic bacteria.

\section{Materials And Methods}

\subsection{Selection of sampling stations and collection of samples}

A total of 7 sampling stations were selected and monthly water samples were collected from all the stations as illustrated in Fig. 1 and sampling was done in the morning from 8-12 hrs. All the sensitive parameters were analysed within 3-6 $\mathrm{h}$ after collection of the samples. For microbiology, after collection, all the samples were stored in cool pack and microbiological platting were made within $6 \mathrm{~h}$ (Haldar et al., 2011). Filtered water after collection were preserved in formaldehyde and analysis was done later. A total of 6-month sampling programme were carried out covering the same stations. The sampling months were October, 2020; January, February, March, April, \& May, 2021.

\subsection{Analytical method for physico-chemical parameters}

The analysis of different physico-chemical parameters of seawater samples i.e. $\mathrm{pH}$, salinity, turbidity, nitrite $\left(\mathrm{NO}_{2}\right)$, nitrate $\left(\mathrm{NO}_{3}\right)$, ammonia $\left(\mathrm{NH}_{3}\right)$, phosphate $\left(\mathrm{PO}_{4}\right)$, total alkalinity and silicate were done as per our previous paper (Haldar et al., 2014) following the detailed methods described in APHA (2017).

\subsection{Bacteriological analysis}


Selective media were used for isolation of different bacterial species from coastal water and all the media were purchased from Hi Media, India. Thiosulfate citrate bile salts sucrose (TCBS) agar were used for culture of pathogenic Vibrio species, MacConkey and MacConkey Sorbitol agar were used for isolation of Escherichia coli, Streptococcus agar was used for isolation of Streptococcus spp., Aeromonas isolation media was used for isolation of Aeromonas hydrophila, xylose-lysine deoxycholate agar was used for isolation of Salmonella spp., Pseudomonas isolation agar was used for isolation of Pseudomonas sp., and M-Enterococcus (ME) agar was used for isolation of Enterococcus. Zobell Marine agar (ZMA) was used for isolation of total heterotrophic bacteria. The detailed culture method was adopted from our previous study (Patel et al., 2014).

\subsection{Statistical analysis}

The statistical analysis of the obtained data was performed and for this purpose, the primary data was rearranged for the ease of analysis. As the sampling points were not very far from each other (0.5-1.0 km apart), there were small variations recorded from the one site to another site. Henceforth, the mean value for each parameter for one-time monthly sampling covering all the stations were considered. Initially, Mann-Kendall trend test for all the 9 parameters were performed to understand the possible trend in 6 months' data obtained from the sites. After Mann-Kendall test (non-zero trend), which may either be linear or non-linear. Mann-Kendall test statistic ("trend package") is calculated according to:

$$
S=\sum_{k=1}^{n-1} \sum_{j=k+1}^{n} \operatorname{sgn}\left(x_{j}-x_{k}\right)
$$

where $\mathrm{S}$ is the trend value, $\mathrm{n}$ is the number of experimental inputs, sgn is the signum function, $x_{j}$ and $x_{k}$ are $\mathrm{j}^{\text {th }}$ and $\mathrm{k}^{\text {th }}$ variables respectively. Thereafter a trend graph was plotted based on the 6-month data obtained from the different sites. Mann-Kendall trend test was performed using 'trend' package of ' $R$ ' statistical software while the graphical plots were generated using MINITAB software.

\section{Results And Discussion}

\subsection{Water health status of Diu coast during lockdown}

A detailed monthly variation in different water quality parameters were analysed and interpreted using Mann-Kendall trend test. Thereafter a trend graph was plotted based on the 6-month data obtained from the different sites. Fluctuations during March, 2021 to May, 2021 were noted when activity were minimum due to 2 nd phase of COVID-19 lockdown. pH of the coastal water is one of the sensitive parameters and overall saline water has an alkaline $\mathrm{pH}$. The $\mathrm{pH}$ values observed in this study varied between 7.7 to 8.2 and for which the $p$-value from the trend test is comparatively low $(0.08517)$ which signifies that the actual value followed predicted trend line as shown in the Fig. 2(a). It is reported that due to anthropogenic activities including vehicular movement, there is an increase in atmospheric carbon dioxide $\left(\mathrm{CO}_{2}\right)$ concentration which finally sink to ocean resulting ocean acidification and $\mathrm{pH}$ reduction 
(Gao et al., 2019). The complete halt of vehicular movement as well as fishing boat during 2 nd phase lockdown would have resulted in the slight reduction of $\mathrm{pH}$.

Salinity values varied between 30-32.5 ppt as shown in Fig. 2(b) where both the trend lines are comparable thus there is a drop of salinity value during April-month sampling and this phenomena is due to no anthropogenic activity. It is observed that there is no particular trend in the monthly salinity data which was evidenced by the greater $p$-value, 0.8404 . The total difference was in between 2.5 ppt only, therefore it has no significant effect on the overall environment. As reverse osmosis-based desalination plants are getting popularized throughout coastal India, one of the major drawback is the release of reject water discharged back to the coastal water which has much higher salinity than normal seawater (Ahuja et al., 2014; Hussain et al., 2019). Due to complete lockdown, the desalination plants were nonoperational, which might be the reason for the reduction of overall salinity during 2 nd phase lockdown sampling.

After 1st lockdown, sampling started from October, 2020 and there was a gradual increase in the value of turbidity upto March, 2021 as shown in the Fig. 3(a). The $p$-value for the trend test of turbidity was observed as 0.0267 , a significant positive trend found in the datasets. Further when 2 nd phase lockdown initiated, a flat trend line was observed in all the stations and this may be due to the fact that reduction of vehicular movement do not have significant impact on the turbidity value. However, an overall upward trend was observed in the total study period.

In case of total alkalinity, when complete lockdown was maintained due to 2nd wave of COVID-19 (April, 2021); a sudden surge of total alkalinity value was observed as in the Fig. 3(b). The obtained $p$-value for the trend test of the total alkalinity is 0.8483 , indicating that there is no regular trend in the monthly total alkalinity data. This variation may be due to sharp increase in value during the month of April, 2021. The reason for sudden increase in total alkalinity was not understood completely. However in May, 2021 again the value came down to the normal level.

There were no regular trends observed for nitrite and nitrate concentrations during this period. Sewage discharges both treated and partially treated as well as other domestic effluents are the major cause for the variation of nutrient concentration in the coastal area (Peters and Meybeck, 2000; Buck et al., 2004; Zhang et al., 2009; Hussain and Badola, 2008; Uddin and Jeong, 2021). However, during the 2nd phase lockdown (March to May, 2021) an interesting relation was observed between $\mathrm{NO}_{3}, \mathrm{NO}_{2}$ and $\mathrm{NH}_{4}-\mathrm{N}$ concentrations as illustrated in the Fig. 4(a-c). Nitrate value was maximum during April, 2021 in comparison with nitrite and ammonia values which may be due to the activity of de-nitrifying and ammonifying bacteria in the water which may convert nitrate to nitrite to ammonia (Zakem et al., 2018). There may be other reactions such as direct reduction from nitrate to ammonium, a process known as dissimilatory nitrate reduction to ammonium or DNRA (An and Gardner, 2002). The obtained $p$-value for nitrate, nitrite and ammonia were $0.08517,0.8483$ and 0.08517 respectively. It can be concluded that the microbial activity was strong during this 2 nd phase lockdown period. 
Silicate values were high at the initial stage (Fig. 5a), then it reduced sharply and maintained an almost straight line during subsequent months. It is already reported that silicate can enter to the coastal water through river discharge, submarine ground water discharge and to a small extent through coastal upwelling (Kumar, 2021). It was also reported that silicate to nitrate ratio has a significant impact on the phytoplankton community in the coastal waters. Further it was also hypothesized that change in silicate to nitrate ratios were the possible reason for the occurrence of frequent harmful algal bloom (HABsdinoflagellates) in the coastal water of Arabian sea (Kumar, 2021). However, no such occurrence was observed during March to May, 2021 in the study area and this was established by high $p$-value $(0.2423)$ signifying that the fluctuations of monthly observed value of silicate may not support the formation of HABs. Imbalance in nitrate and phosphate ratio causes eutrophication and in the present study there was no significant trend of average phosphate concentration because the $p$-value is 0.8483 . The phosphate concentration was near minimal during April, 2021 sampling as illustrated in Fig. 5b. As phosphate has a huge impact on primary productivity of coastal water, this outcome predicts that the primary productivity was low during the 2 nd phase lockdown. The statistical values and their correlations from trend analysis are enlisted in Table 1.

Table 1

Statistical coorelations from the trend analysis for the parameters

\begin{tabular}{|c|c|c|c|c|c|}
\hline Parameters & Equation & MAPE & MSD & MAD & $p$-value \\
\hline $\mathrm{pH}$ & $\begin{array}{l}Y t=7.547+ \\
0.1203 \times t\end{array}$ & 0.957837 & 0.008950 & 0.076451 & 0.08517 \\
\hline Turbidity (NTU) & $Y t=2.956+0.447 \times t$ & 9.12586 & 0.20973 & 0.40000 & 0.02677 \\
\hline Total alkalinity (mg/L) & $Y t=10.45+1.05 \times t$ & 20.9923 & 19.0209 & 3.2867 & 0.8483 \\
\hline Salinity (ppt) & $Y t=31.667-0.029 \times t$ & 1.86737 & 0.45651 & 0.58730 & 0.8404 \\
\hline Nitrate nitrogen $(\mathrm{mg} / \mathrm{L})$ & $\begin{array}{l}Y t=0.428+ \\
0.3469 \times t\end{array}$ & 17.9825 & 0.0911 & 0.2797 & 0.8483 \\
\hline Phosphate (mg/L) & $Y t=0.404-0.0457 \times t$ & 146.385 & 0.029 & 0.163 & 0.8483 \\
\hline $\begin{array}{l}\text { Ammonium nitrogen } \\
(\mathrm{mg} / \mathrm{L})\end{array}$ & $Y t=0.734-0.1221 \times t$ & 58.4933 & 0.0297 & 0.1416 & 0.08517 \\
\hline Silicate (mg/L) & $Y t=9.43-1.493 \times t$ & 64.8715 & 7.2636 & 2.2934 & 0.2423 \\
\hline Nitrite nitrogen (mg/L) & $\begin{array}{l}Y t=0.233+ \\
0.4229 \times t\end{array}$ & 15.8708 & 0.0830 & 0.2380 & 0.08517 \\
\hline
\end{tabular}

\subsection{Microbiological data}

It was observed that during October, 2020 the total bacterial load, Vibrio load, Enterococcus load were high and was reduced gradually during March and April 2021 sampling. However the upward trend was recorded during May, 2021 sampling which indicates the commencement of anthropogenic activities. In a 
recent study, at similar pristine environment at Gulf of Mannar (eastern part of India) similar trend of bacterial load was observed after lockdown sampling (Edward et al., 2021).

\subsection{Relationship between selected physico-chemical parameter and bacterial load in the coastal water}

Among the different physico-chemical parameters tested, there is a sudden fluctuation of alkalinity values in the 6-month sampling data. The principal component analysis (PCA) covering all the physicochemical parameters and different selected bacterial counts. The outcome of PCA revealed that the total alkalinity value formed a close cluster with all the bacterial load value (Fig. 6) while the other physicochemical parameters formed separate clusters. Therefore, it was assumed that total alkalinity value of water may have an influence on differential bacterial load. Further, the relationship between these two variables viz., total alkalinity and the bacterial load were established using correlation test followed by regression analysis to evalaute the linear relationship among them. Total alkalinity, a measure of the ability of a solution to resist a change in $\mathrm{pH}$ and is one of the important parameter that describe the seawater carbonate system (Rheuban et al., 2021). Since the industrial revolution, fossil fuel burning and land use changes have resulted in significant amount of carbon dioxide release and global warming (Lelieveld et al., 2019). Thus far about one-third of this emitted $\mathrm{CO}_{2}$ has been taken up by the ocean (Sabine et al., 2004; Sabine and Feely, 2007), although previously it was reported that burial of calcium carbonate $\left(\mathrm{CaCO}_{3}\right)$ have focused on pelagic open ocean production and sink within deep-sea sediments (O'Mara and Dunne, 2019). Later it was revealed that despite representing less than $7 \%$ of the seafloor, coastal and continental shelf (neritic) environments of less than $200 \mathrm{~m}$ water depth account for more than half of all $\mathrm{CaCO}_{3}$ accumulation in ocean sediment globally (Milliman, 1993; Milliman and Droxler, 1996; Iglesias-Rodriguez et al., 2002). In general, absorption of $\mathrm{CO}_{2}$ in the coastal water depends on many factors such as freshwater discharge, stratification, water resident time, eutrophication and upwelling (Rheuban et al., 2021). In a time series study from 2007 to 2015, it was reported that synchronous increase in total alkalinity were faster during spring-summer transition and it is an useful indicator of marine ecosystems' vulnerability to acidification pressure from various $\mathrm{CO}_{2}$ sources (Kapsenberg et al., 2017). However, total alkalinity is not typically monitored by community science organizations because of financial and analytical barriers. In general, it was reported that increase in nitrate and phosphate can cause a small decrease in total alkalinity (Wolf-Gladrow et al., 2007). Therefore, it can be assumed that total alkalinity may have an influence on the different bacterial load, eventually to the overall coastal health.

It was already reported that coastal water is the hotspot for the reservoir of different pathogenic bacteria (Shinde et al., 2020). Further, cases of water borne diseases are directly related to their primary proximity to the coast (Batabyal et al., 2014). Therefore, monitoring the different pathogenic bacterial load is eminent to understand the coastal water quality in a better way. As alkalinity has a long term impact on different physico-chemical parameters and also the PCA analysis shows that the different bacterial load has a relation (formed same cluster in PCA plot) with total alkalinity value. An attempt was further made 
to derive a mathematical relationship (regression analysis) between obtained total alkalinity value and the differential bacterial loads.

It was observed that total bacterial count derived by platting in ZMA medium and other differential bacterial counts such as TCBS, Mac Conkey-S, AIM, XLD, PIM showed the relationship with total alkalinity by the equations mentioned in the Table 2 . Further, these equations were validated with the obtained data. In a previous study it was reported that among different physico-chemical parameters, $\mathrm{pH}$ was the only statistically significant factor influencing the bacterial load (Salazar et al., 2020). Upto our understanding this is the first report which can provide differential bacterial load in the coastal water by formulating a mathematical correlation with the common physico-chemical parameter like total alkalinity.

Table 2

Mathematical relationship between the bacterial mean value and the total alkalinity

\begin{tabular}{|c|c|c|c|c|}
\hline $\begin{array}{l}\text { Media used for } \\
\text { culture }\end{array}$ & $\begin{array}{l}\text { Type of bacterial } \\
\text { cultures }\end{array}$ & Regression equation & $\begin{array}{l}\text { Correlation } \\
\text { value }\end{array}$ & $p$-value \\
\hline ZMA & $\begin{array}{l}\text { Total Bacteria } \\
\text { counts }\end{array}$ & $\begin{array}{l}\text { ZMA Mean }=-728+1138.8 \times \text { total } \\
\text { alkalinity }\end{array}$ & 0.9643581 & 0.001883 \\
\hline TCBS & Vibrio load & $\begin{array}{l}\text { TCBS Mean }=-114.12+10.044 \times \\
\text { total alkalinity }\end{array}$ & 0.9968413 & $\begin{array}{l}1.495 \mathrm{e}- \\
05\end{array}$ \\
\hline Mac Conkey S & Escherichia coli & $\begin{array}{l}\text { Mac. S Mean }=-118.04+10.13 x \\
\text { total alkalinity }\end{array}$ & 0.9983208 & $\begin{array}{l}4.227 e- \\
06\end{array}$ \\
\hline AIM & $\begin{array}{l}\text { Aeromonas } \\
\text { hydrophila }\end{array}$ & $\begin{array}{l}\text { AIM Mean }=-114.12+10.044 \times \\
\text { total alkalinity }\end{array}$ & 0.9948055 & $4.04 \mathrm{e}-05$ \\
\hline XLD & Salmonella spp. & $\begin{array}{l}\text { XLD Mean }=-12.63+1.189 \times \text { total } \\
\text { alkalinity }\end{array}$ & 0.9704215 & 0.001299 \\
\hline PIM & Pseudomonas sp. & $\begin{array}{l}\text { PIM Mean }=-25+10.8 \times \text { total } \\
\text { alkalinity }\end{array}$ & 0.5171161 & 0.2935 \\
\hline
\end{tabular}

\section{Conclusions}

A detailed study was carried out to understand the impact of 2nd phase COVID-19 lockdown from March to May 2021, on different physico-chemical parameters by analyzing monthly average data of Diu coast, India. Due to the cessation of anthropogenic activity including tourist movement, sudden change of $\mathrm{pH}$, salinity, nitrite, nitrate and phosphate values were observed. Also there was a decreasing trends of different bacterial counts during this period (April, 2021). PCA study including all the physico-chemical and bacteriological counts showed there is single cluster of total alkalinity with all the differential bacterial count. Further, mathematical correlation between total alkalinity and all other bacterial loads obtained by platting in different selective media was derived. The outcome of the work helps to predict the different bacterial load by only understanding the total alkalinity value of the study area which will have significant impact for understanding the coastal health. 


\section{Declarations}

Ethical approval and consent to participate: The authors declare that they have no known competing financial interests or personal relationships that seem to affect the work reported in this article.

Consent for Publication: We do not have any individual person's data in any form.

Availability of data and materials: Not applicable

Competing interest: The authors declare that they have no conflict of interest.

Funding: Authors sincerely thank INCOIS-MoES for financial support to carry out the project work. TPS and AHS acknowledge INCOIS-MoES for financial support.

\section{Authors contribution}

Atanu Kumar Panja: data curation and writing-original draft. Sonpal Vasavdutta: data curation. Tarini Prasad Sahoo: data curation. Ambika H. Shinde: data curation. Ravikumar B. Thorat: review and editing. Shruti Chatterjee: review and editing. Sanak Ray: review and editing. Madhava Anil Kumar: visualization, review and editing. Soumya Haldar: conceptualization, visualization, review, supervision and editing. All authors read and approved the manuscript.

\section{Acknowledgement}

Authors also acknowledge Mr. Narshi R Baraiya for field sampling. Authors also sincerely acknowledge the Centralized Instrument Facility for analysis support. This manuscript has been assigned with CSIRCSMCRI: 209/2021 registration.

\section{References}

1. Ahuja S, Larsen MC, Eimers JL, Patterson CL, Sengupta S, Schnoor JL (2014) Comprehensive water quality and purification. Elsevier, Amsterdam

2. An S, Gardner WS (2002) Dissimilatory nitrate reduction to ammonium (DNRA) as a nitrogen link, versus denitrification as a sink in a shallow estuary Laguna Madre/Baffin Bay, Texas. Marine Ecol Progress Ser 237:41-50

3. APHA (2017) Standard methods for the examination of water and wastewater. American Public Health Association/American Water Works Association/Water Environment Federation, Washington DC, USA

4. Batabyal P, Mookerjee S, Einsporn MH, Lara RJ, Palit A (2014) High prevalence of toxin producing enteropathogenic Vibrios among estuarine crab in Ganges delta of West Bengal, India. Infection, genetics and evolution. Infect Genet Evol 26:359-361 
5. Buck O, Niyogi DK, Townsend CR (2004) Scale-dependence of land use effects on water quality of streams in agricultural catchments. Environ Pollut 130:287-299

6. Chanchpara A, Sonpal V, Mehta G, Sahoo TP, Thorat RB, Ray S, Haldar S (2021) New normal baseline data during nationwide lock down due to Covid 19 pandemic in the world's largest ship recycling yard at Alang, India. Environ Sci Pollut Res Int 28:35051-35063

7. Department of Fisheries (2019) Handbook on Fisheries Statistics, New Delhi. Handbook on FS2018.pdf. https://dof.gov.in/sites/default/files/2020-08/

8. Edward JP, Jayanthi M, Malleshappa H, Jeyasanta KI, Laju R, Patterson J, Raj KD, Mathews G, Marimuthu A, Grimsditch G (2021) COVID-19 lockdown improved the health of coastal environment and enhanced the population of reef-fish. Marine Poll Bull 165:112124

9. Fisheries Department D (2013) The details of Fishing Crafts Operating in Diu District. http://diu.gov.in/fishcraft.html

10. Gao K, Beardall J, Häder D-P, Hall-Spencer JM, Gao G, Hutchins DA (2019) Effects of ocean acidification on marine photosynthetic organisms under the concurrent influences of warming, UV radiation, and deoxygenation. Front Mar Sci 6:322

11. Gopal V, Shanmugasundaram A, Nithya B, Magesh N, Jayaprakash M (2018) Water quality of the Uppanar estuary, Southern India: implications on the level of dissolved nutrients and trace elements. Marine Poll Bull 130:279-286

12. Haldar S, Mandal SK, Thorat RB, Goel S, Baxi KD, Parmer NP, Patel V, Basha S, Mody KH (2014) Water pollution of Sabarmati River - a Harbinger to potential disaster. Environ Monit Assess 186:22312242

13. Haldar S, Mody KH, Jha B (2011) Abundance, diversity and antibiotics resistance pattern of Vibrio spp. in coral ecosystem of Kurusadai island. J Basic Microbiol 51:153-162

14. Hussain MS, Abd-Elhamid HF, Javadi AA, Sherif MM (2019) Management of seawater intrusion in coastal aquifers: a review. Water 11:2467

15. Hussain SA, Badola R (2008) Valuing mangrove ecosystem services: linking nutrient retention function of mangrove forests to enhanced agroecosystem production. Wetlands Ecol Manage 16:441-450

16. Iglesias-Rodriguez MD, Armstrong R, Feely R, Hood R, Kleypas J, Milliman JD, Sabine C, Sarmiento J (2002) Progress made in study of ocean's calcium carbonate budget. Eos, Transactions American Geophys Union 83:365-375

17. Kapsenberg L, Alliouane S, Gazeau F, Mousseau L, Gattuso J-P (2017) Coastal Ocean acidification and increasing total alkalinity in the northwestern Mediterranean Sea. Ocean Sci 13:411-426

18. Khatri N, Tyagi S (2015) Influences of natural and anthropogenic factors on surface and groundwater quality in rural and urban areas. Front in Life Sci 8:23-39

19. Kumar B (2021) Spatial and temporal variations in dissolved silicate along the Indian coastal groundwaters and their export to adjacent coastal waters. Groundw Sustain Dev 14:100637 
20. Lelieveld J, Klingmüller K, Pozzer A, Burnett RT, Haines A, Ramanathan V (2019) Effects of fossil fuel and total anthropogenic emission removal on public health and climate. PNAS 116:7192-7197

21. Lotliker AA, Baliarsingh SK, Shesu RV, Samanta A, Naik RC, Nair TB (2021) Did the Coronavirus Disease 2019 Lockdown Phase Influence Coastal Water Quality Parameters off Major Indian Cities and River Basins? Front Mar Sci. https://doi.org/10.3389/fmars.2021.648166

22. Milliman J, Droxler A (1996) Neritic and pelagic carbonate sedimentation in the marine environment: ignorance is not bliss. Geolo Runds 85:496-504

23. Milliman JD (1993) Production and accumulation of calcium carbonate in the ocean: Budget of a nonsteady state. Global Biogeochem Cy 7:927-957

24. NIP Ltd (2020) Tourism Survey for Daman \& Diu, Ministry of Tourism, India. https://tourism.gov.in/sites/default/files/202004/Tourism\%20Survey\%20Reporty\%20\%28January\%20December\%2C\%202014\%29\%20-\%20Daman\%20Diu.pdf

25. O'Mara NA, Dunne JP (2019) Hot spots of carbon and alkalinity cycling in the coastal oceans. Scientific Rep 9:4434

26. Patel M, Baxi K, Dayma P, Upadhyay D, Parmar N, Kundu S, Haldar S, Mody KH, Jha B (2014) Assessment of ground water quality with respect to bacteriological contamination in Bhavnagar, Gujarat, India. Clean-Soil, Air, Water 42:1351-1362

27. Peters NE, Meybeck M (2000) Water quality degradation effects on freshwater availability: impacts of human activities. Water Int 25:185-193

28. Rheuban J, Gassett P, McCorkle D, Hunt C, Liebman M, Bastidas C, O’Brien-Clayton K, Pimenta A, Silva E, Vlahos $P$ (2021) Synoptic assessment of coastal total alkalinity through community science. Environ Res Lett 16:024009

29. Sabine CL, Feely RA (2007) The oceanic sink for carbon dioxide. In: Reay D, Hewitt N, Grace J, Smith K (eds) Greenhouse Gas Sinks. CABI Publishing, Oxfordshire, UK, pp 31-49

30. Sabine CL, Feely RA, Gruber N, Key RM, Lee K, Bullister JL, Wanninkhof R, Wong CL, Wallace DWR, Tilbrook B, Millero FJ, Peng T-H, Kozyr A, Ono T, Rios AF (2004b) The oceanic sink for anthropogenic $\mathrm{CO}_{2}$. Science 305(5682):367-371

31. Salazar NR, Aguirre C, Soto J, Salinas P, Salinas C, Prieto H, Paneque M (2020) Physicochemical parameters affecting the distribution and diversity of the water column microbial community in the high-altitude Andean lake system of La Brava and La Punta. Microorganisms 8:1181

32. Shinde AH, Raval IH, Haldar S (2020) SXT int harboring bacteria as effective indicators to determine high-risk reservoirs of multiple antibiotic resistance in different aquatic environments of western coast of Gujarat, India. Ecol Indic 113:106143

33. Uddin MJ, Jeong Y (2021) Urban river pollution in Bangladesh during last 40 years: potential public health and ecological risk, present policy, and future prospects toward smart water management. Heliyon 7:e06107 
34. Verlecar XN, Desai SR, Sarkar A, Dalal S (2006) Biological indicators in relation to coastal pollution along Karnataka coast, India. Water Res 40:3304-3312

35. Wolf-Gladrow DA, Zeebe RE, Klaas C, Körtzinger A, Dickson AG (2007) Total alkalinity: The explicit conservative expression and its application to biogeochemical processes. Mar Chem 106:287-300

36. Zakem EJ, Al-Haj A, Church MJ, van Dijken GL, Dutkiewicz S, Foster SQ, Fulweiler RW, Mills MM, Follows MJ (2018) Ecological control of nitrite in the upper ocean. Nat Commun 9:1206

37. Zhang Q, Li Z, Zeng G, Li J, Fang Y, Yuan Q, Wang Y, Ye F (2009) Assessment of surface water quality using multivariate statistical techniques in red soil hilly region: a case study of Xiangjiang watershed, China. Environ Monit Assess 152:123-131

38. Zingde M, Govindan K (2000) Health status of the coastal waters of Mumbai and regions around. http://drs.nio.org/drs/handle/2264/1635

\section{Figures}

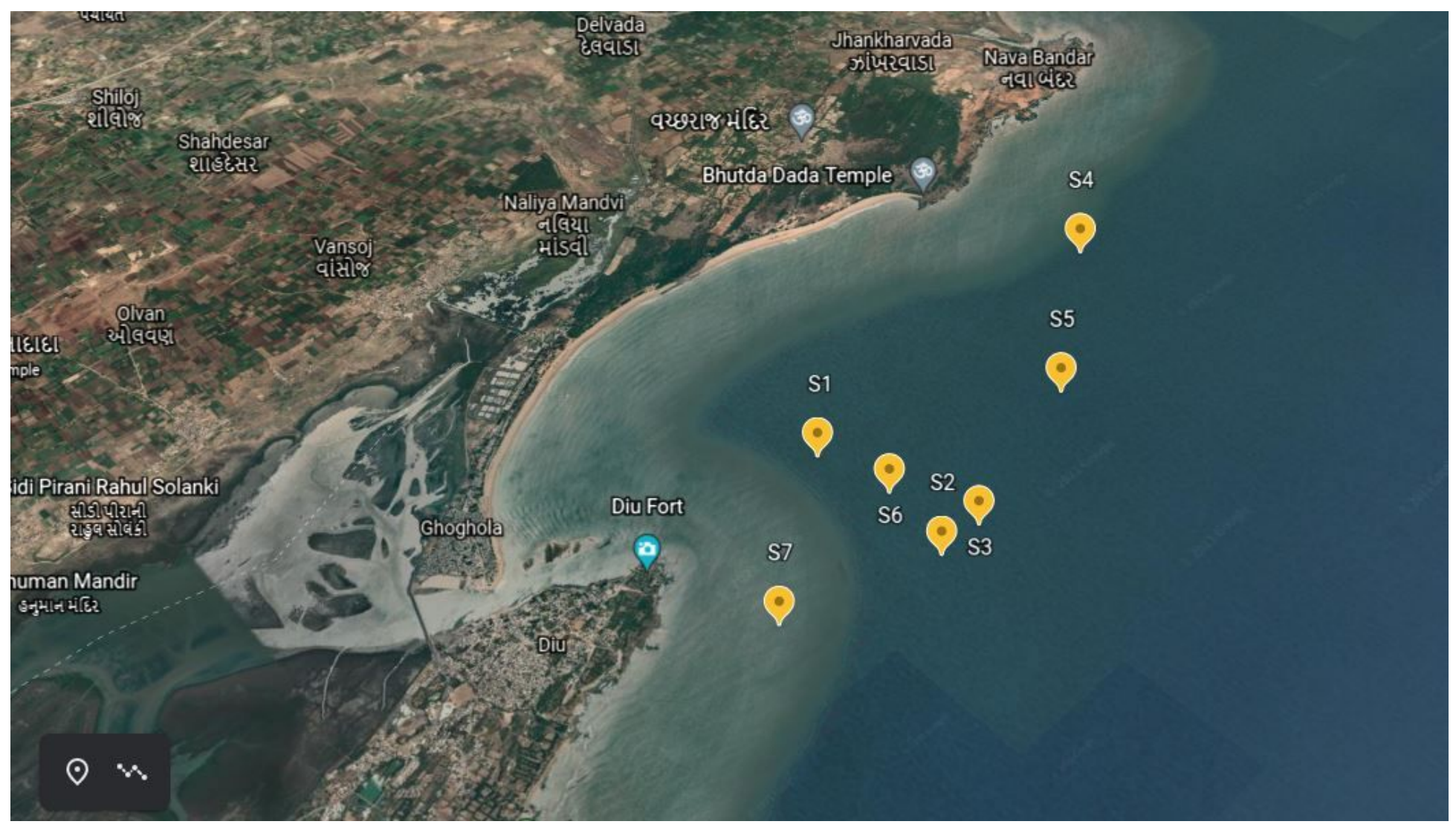

\section{Figure 1}

Map showing the selected sampling locations 

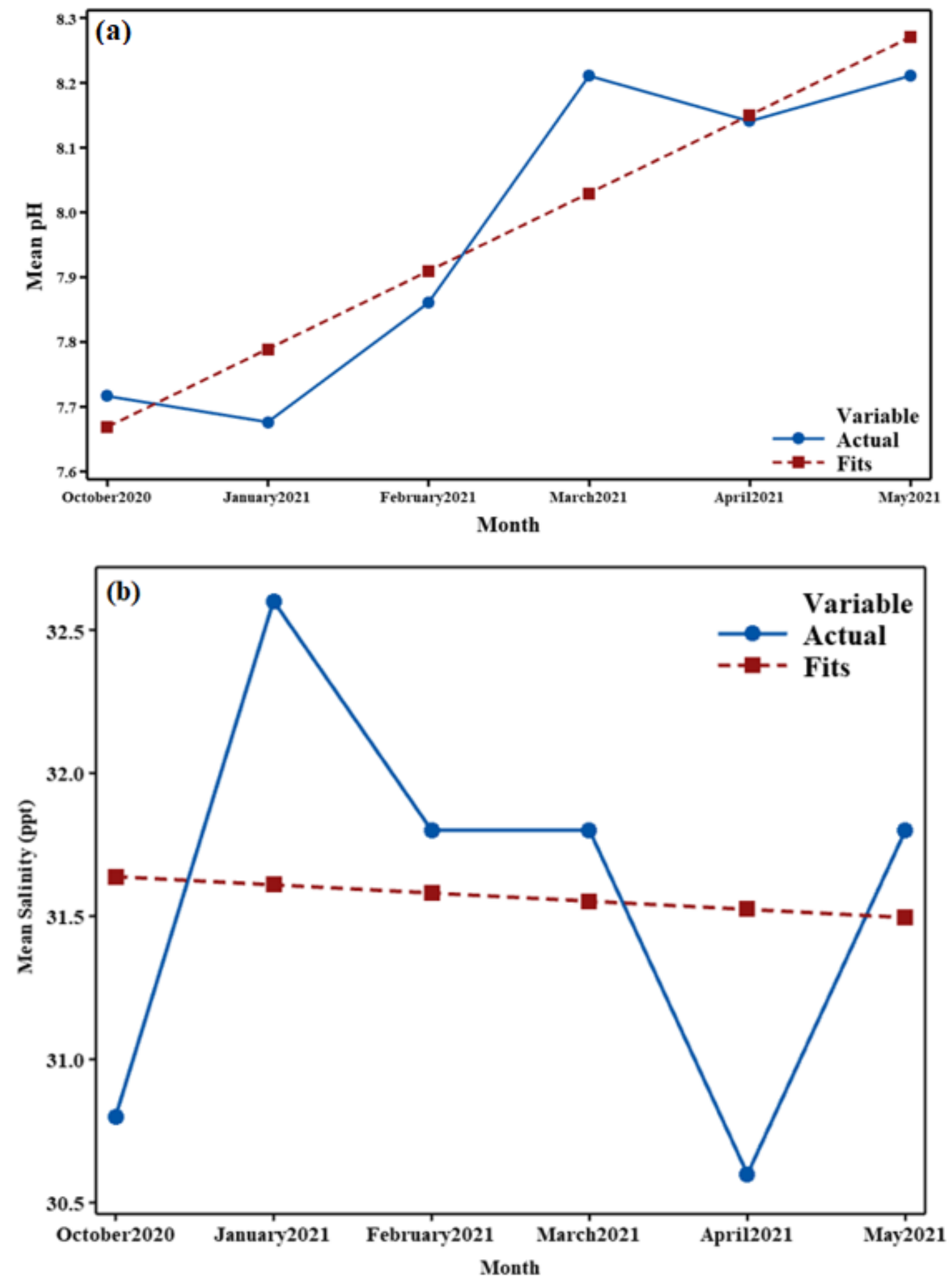

Figure 2

Trend analysis plot for the monthly fluctuation of (a) $\mathrm{pH}$ and (b) salinity in all stations 

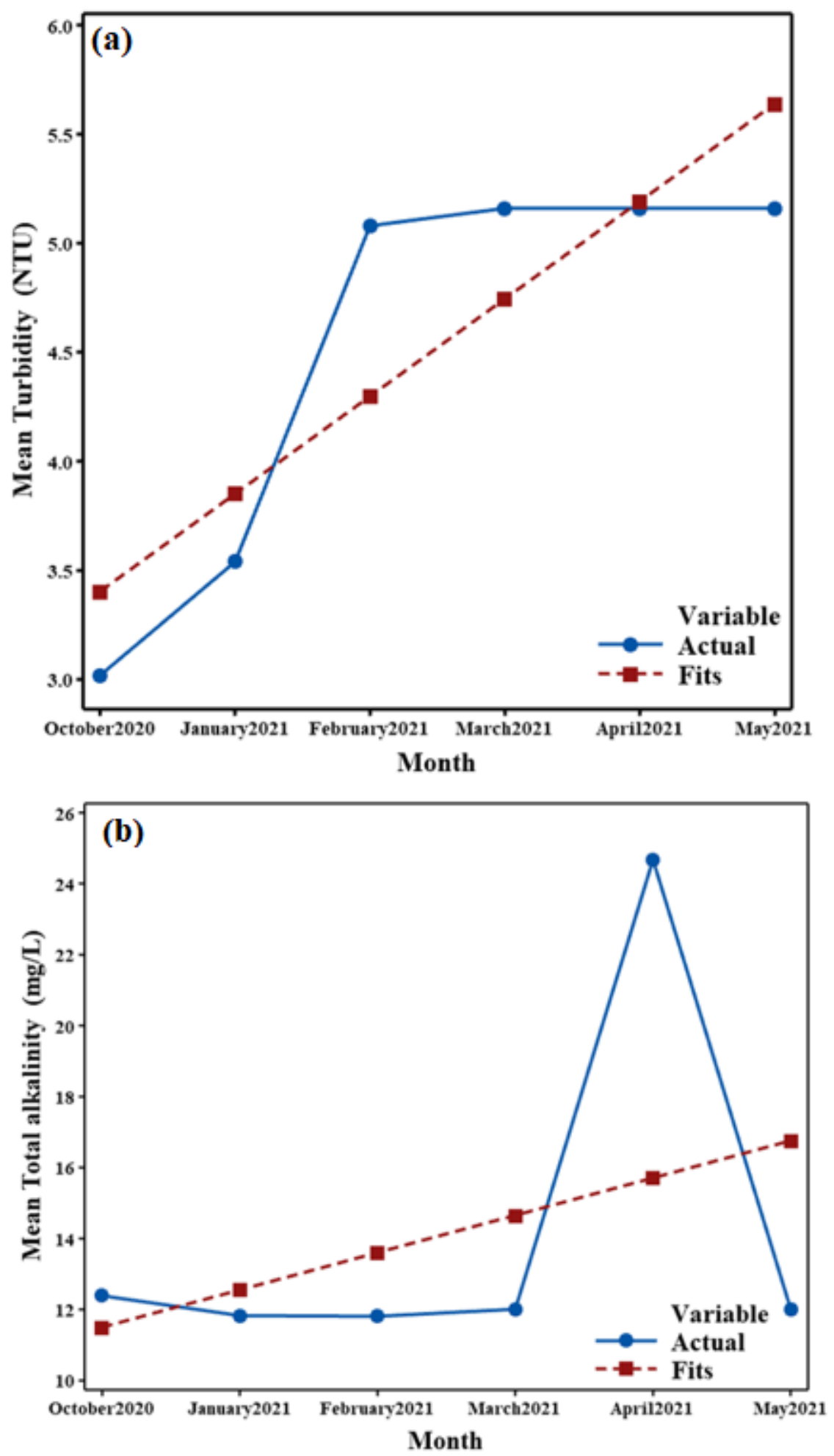

\section{Figure 3}

Trend analysis plot for the monthly fluctuation of (a) turbidity and (b) total alkalinity in all stations 

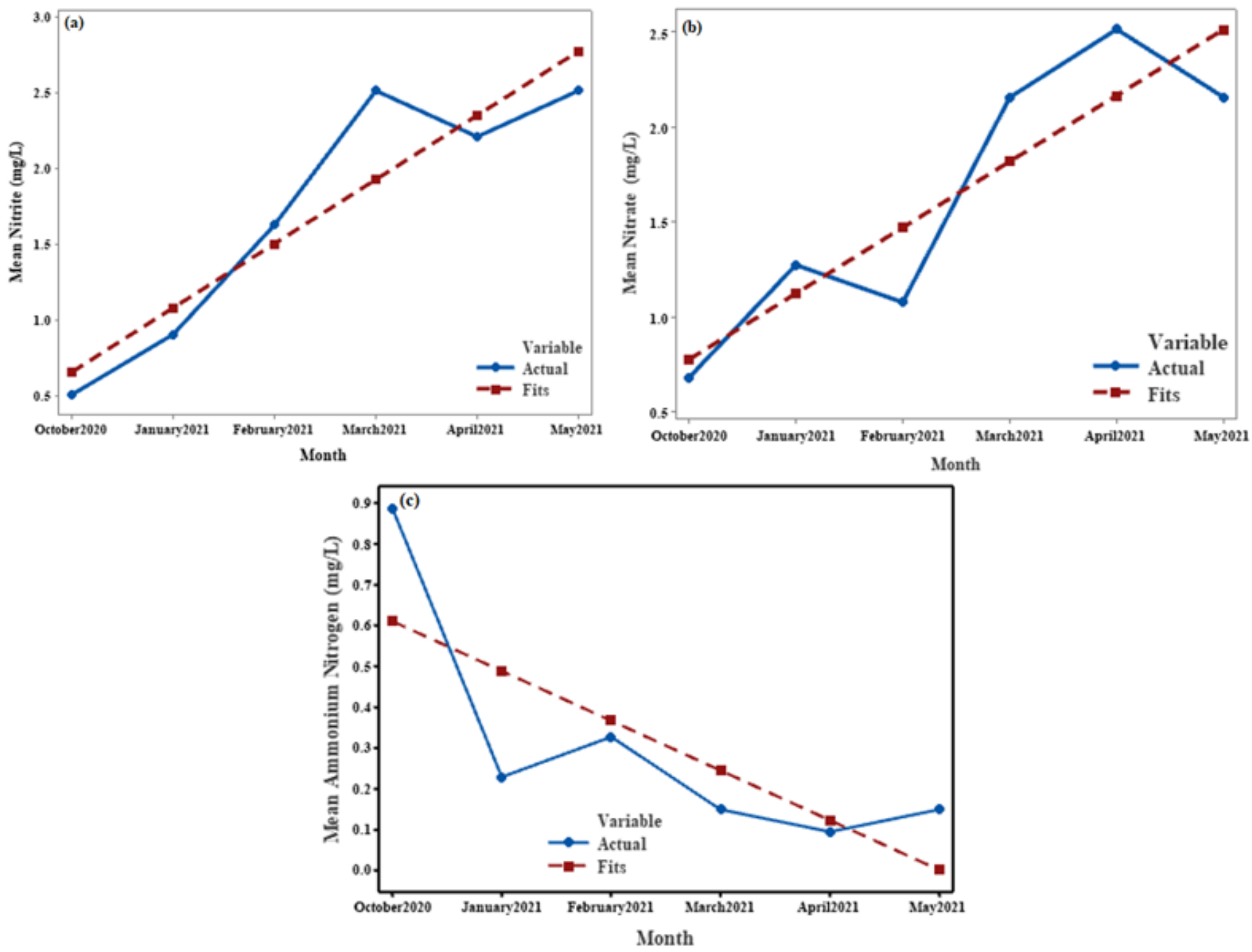

Figure 4

Trend analysis plot for the monthly fluctuation of (a) nitrite, (b) nitrate and (c) ammonium nitrogen in all stations 

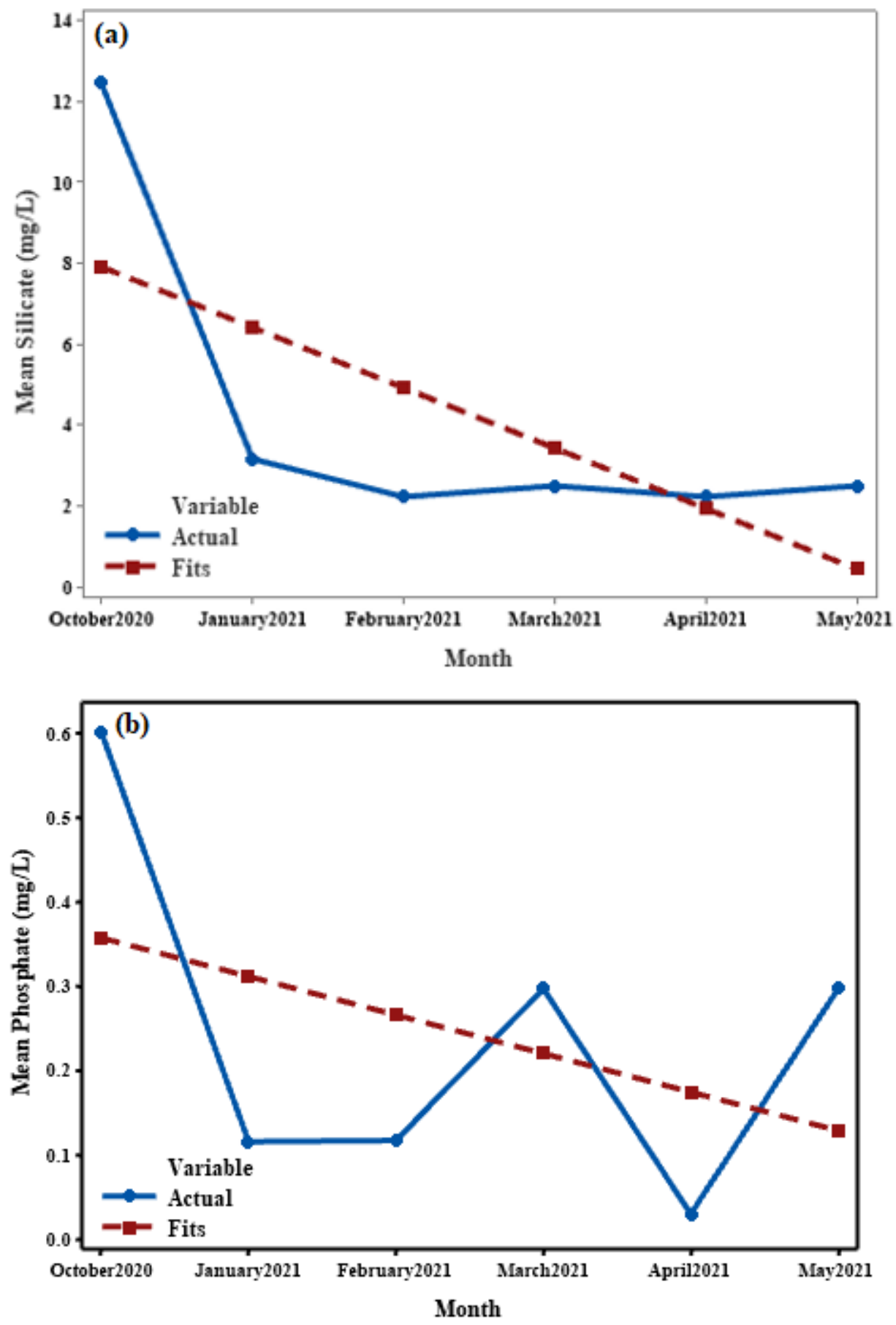

Figure 5

Trend analysis plot for the monthly fluctuation of (a) silicate and (b) phosphate in all stations 


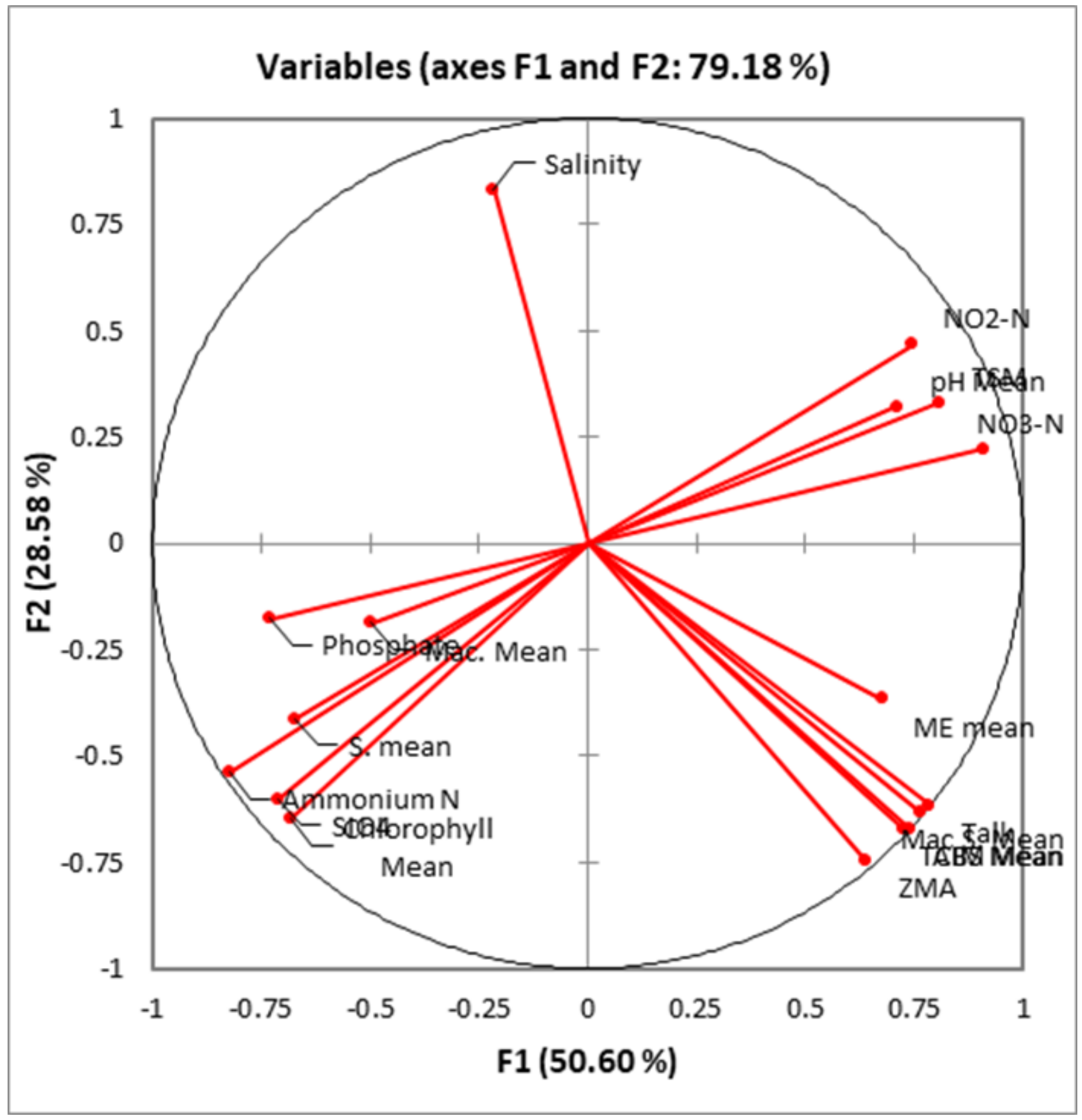

Figure 6

PCA plot of bacterial load with physico-chemical parameters 